\title{
Spatial Clustering of Foreign Direct Investment: The Case of Japanese Automotive Suppliers in Mexico
}

\section{Clústeres espaciales de la inversión extranjera directa: el caso de proveedores automotrices japoneses en México}

\author{
DOI: $10.32870 /$ mycp.v10i29.720
}

\author{
María Guadalupe Lugo-Sánchez ${ }^{1}$ \\ Leo Guzmán-Anaya ${ }^{2}$
}

\begin{abstract}
The arrival of Japanese investment in the Mexican automotive industry has caused an increase in the economic dynamism of the Bajio region, especially since the entry into force of the Mexico-Japan Economic Partnership Agreement in 2005. Previous research has been conducted from different perspectives explaining the spatial distribution and agglomeration of Japanese enterprises in host countries; however, studies that employ measurements of spatial clustering for Japanese firms are still scarce. For the present research, a unique spatial georeferenced database of Japanese automotive suppliers was created to identify the clustering patterns of firms. The results suggest that Japanese automotive supplier firms in Mexico favor spatial proximity. The use of spatial measurements of concentration provides evidence to further understand the presence of agglomeration of Japanese firms in the automotive industry.
\end{abstract}

Keywords: spatial clustering, Japanese foreign direct investment, automotive industry, automotive supplier, Mexico.

\section{Resumen}

La llegada de inversión japonesa a la industria automotriz en México ha incrementado el dinamismo económico de la zona del Bajío, especialmente desde la entrada en vigor del Acuerdo de Asociación Económica México-Japón en el año 2005. Estudios previos han buscado desde diferentes perspectivas explicar la distribución espacial y la aglomeración de empresas japonesas en países receptores. Sin embargo, investigaciones que utilicen métodos de medición de clústeres espaciales para empresas japonesas son todavía escasas. En la presente investigación se utiliza una base de datos única con información georreferenciada de proveedores automotrices japoneses con la finalidad de identificar patrones de tipo clúster y aglomeración de las empresas. Los resultados sugieren que las empresas automotrices proveedoras japonesas en México favorecen proximidad espacial. El uso de medidas de concentración espacial otorga evidencia para comprender mejor la presencia de aglomeración de empresas japonesas en la industria automotriz.

Palabras clave: clúster espacial, inversión extranjera directa de Japón, industria automotriz, proveeduría automotriz, México.

Artículo recibido el 24 de agosto de 2020 y dictaminado el 30 de diciembre de 2020.

1. Universidad de Guadalajara, Centro Universitario de Ciencias Económico Administrativas (CUCEA). Periférico Norte 799 C.P. 45100, Zapopan, Jalisco, México. ORCID: https://orcid.org/0000-00017765-8968 Correo electrónico: lugsan@cucea.udg.mx

2. Universidad de Guadalajara, Centro Universitario de Ciencias Económico Administrativas (CUCEA). Periférico Norte 799 C.P. 45100, Zapopan, Jalisco, México. ORCID: https://orcid.org/0000-00025682-3175 Correo electrónico: leo@academicos.udg.mx 


\section{Introduction}

Foreign Direct Investment (hereafter FDI) has been regarded as a factor that stimulates economic growth. It has been argued by empirical and theoretical literature that recipient countries may benefit from the externalities or the spillover effects associated with this type of investment. In this sense, many governments from both developed and developing nations eased restrictions on FDI since the 1980s, and many of them actively pursued to attract foreign investors through government subsidies and tax incentives. After forty years since the world embraced capital mobility, there is still an ongoing debate on the real benefits from FDI to the host countries.

Mexico was among the Latin American countries that expected FDI to stimulate economic growth and development. After the debt crisis of the 1980s, Mexico restructured its economy and policies were implemented to transition from import substitution to an export promotion development strategy. The country gradually increased its openness to free trade and foreign investment and implemented fierce public policies including tax incentives and subsidies to attract FDI.

The signing of NAFTA in the 1990s was crucial to Mexico's economy for the promotion of manufacturing exports that were based on FDI; trade increased between Mexico and the United States because of NAFTA and investment flows to Mexico registered an upward trend with the arrival of manufacturing plants to the shared border of the two countries, making Mexico an attractive destination for FDI (see Figure 1). The attraction of FDI became an important government strategy for Mexico's economic development and an important issue for policymakers.

For Mexico, openness of the economy continued to the point that the country currently has a network of 13 Free Trade Agreements with 50 countries, 32 Reciprocal Investment Promotion and Protection Agreements (RIPPAS) with 33 countries, and nine Trade Agreements (Economic Complementation and Partial Scope Agreements) within the framework of the Latin American Integration Association (ALADI in Spanish). Also, restrictions on FDI have gradually dropped during the last forty years according to OECD standards, and this receptiveness to foreign investment has been more noticeable for the automotive industry where restrictions are below OECD levels and below other manufacturing industries (Lichtensztejn, 2014). 


\section{Figure 1}

Foreign Direct Investment Flows to Mexico, 1980-2019

FDI FLOWS TO MEXICO

(CURRENT PRICES, MDD)

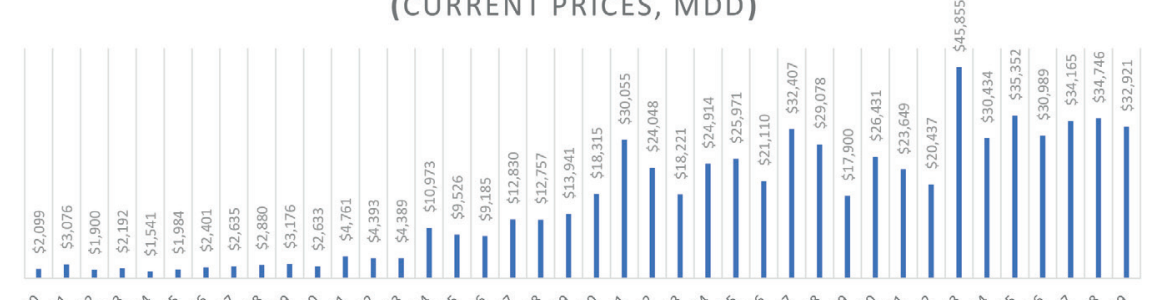

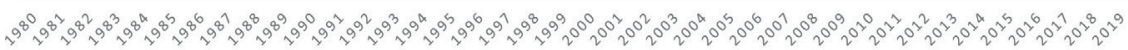

Source: Authors' elaboration with data from UNCTAD (2020).

Previous literature has studied the spatial distribution of FDI. For the case of Japanese FDI, previous studies highlight the agglomeration preference of Japanese companies, and for the automotive industry (Smith \& Florida, 1994). Japanese automotive suppliers that invest abroad seem to favor an agglomeration preference where their particular organizational and productive structure favors proximity to firms that are integrated into the supply chain (Asanuma, 1989; Belderbos \& Carree, 2002).

This type of network-related business investment overseas facilitates the transition and arrival of other Japanese companies facilitating the establishment of just-in-time delivery and control systems, the development of long-term supplier relationships, and the increase of specialized amenities (Japanese schools, restaurants, and other specialized services) (Reid, 1995; Head et al., 1995). Empirically, the agglomeration of Japanese automotive FDI has been widely researched in the U. S., Europe, and China (Belderbos \& Carree, 2002; Cheng \& Stough, 2006; Smith \& Florida, 1994; Zhou et al., 2002).

For the case of Mexico, studies have shown that Japanese firms agglomerate in regions such as Aguascalientes and Guanajuato (Kakihara \& Guzman, 2014) and that agglomeration is an important factor in the location decision of Japanese manufacturing firms (Guzman-Anaya, 2018).

However, the previous literature on Japanese firm agglomeration typically employs mesoeconomic measurements of spatial distribution of economic activities. These techniques fail to capture the a-spatial nature of the data and are insensitive to any permutation of spatial units. The current study 
will attempt to overcome these shortcomings by creating a unique database with georeferenced information on the location of Japanese Tier-1 and Tier-2 automotive suppliers. The data will allow the use of research methods that account for spatial dependence in the data using firm-level information aggregated at the municipality level. The results will advance the current literature on the Japanese FDI agglomeration of automotive suppliers using the case of Mexico.

\section{Mexico's Automotive Industry}

As mentioned earlier, with the implementation of NAFTA in 1994, restrictions on automotive FDI were reduced dramatically and this promoted the arrival of companies in certain regions within Mexico. The development of the automotive and auto parts industries created production enclaves mainly in the center and northern regions of Mexico. This contributed to geographical distribution of economic activity outside of Mexico City. The states of Aguascalientes, Baja California, Chihuahua, Coahuila, Guanajuato, Hidalgo, Jalisco, Estado de Mexico, Morelos, Nuevo Leon, Puebla, Queretaro, San Luis Potosi, and Sonora have transport equipment production. The distribution of the Mexican automotive industry thus created a supply chain that can adapt to changing demand and natural disasters while providing competitive costs. Because of NAFTA, a supply chain characterized by domestic and "near-shore" production within the region was developed and interconnected Mexico, the United States, and Canada. The production preference of parts and components in Mexico helped to develop and maintain a competitive automotive industry across North America that might have otherwise moved offshore to countries in Asia, Eastern Europe, or South America (Dziczek et al., 2017).

By 2000, further restrictions to FDI were aimed at eliminating the national content requirement on new vehicles and facilitated the location of production within major Mexican cities (Lichtensztejn, 2014). After the 2008 financial crisis, Mexico regained a position as an attractive manufacturing destination, since firms shifted from cost-optimization strategies and searched for proximity to suppliers expecting a more efficient input provision, primarily for the North American automotive market. From Mexico's total automotive production, $73 \%$ is concentrated solely in the United States and Canada. The shift in production incentivized the movement of plants from American, European, and Asian origin to Mexico seeking to take advantage 
of quality manufacturing and a cost-competitive environment along with the preferential benefits of NAFTA and Mexico's other thirteen Free Trade Agreements (FTAs) that provide access to fifty countries and over $60 \%$ of world GDP (Global Business Reports, 2016).

The development of the automotive industry in Mexico created automotive regions distributed in the Northeast (Nuevo Leon, Coahuila, Chihuahua, and Tamaulipas), the South-Central (Mexico State, Tlaxcala, Puebla, Morelos), and the Bajio (Queretaro, Guanajuato, Jalisco, San Luis Potosi, and Aguascalientes). The automotive industry organized the creation of the automotive clusters named "CLAUT", which were formed to establish a support network that eases interaction between firms and as a way to share the industry's best practices. Also, CLAUTs seek to transfer technological knowledge from foreign to local firms expecting the industry to transition from the manufacturing stage towards an era of design and innovation (Global Business Reports, 2016).

Mexican development agencies have also set forward strategies to attract R\&D centers aimed at the automotive industry and its supporting industry. It has been argued that for the automotive industry, the processes related to stamping, foundry, machining, semiconductors, and plastic injection provide an area of opportunity for local suppliers since these goods provide the most value-added and most of them are still being imported. Also, in the medium term, the country must seek to transition from a solely manufacturing hub to activities related to design engineering and tool manufacturing.

The Mexican automotive industry includes 20 of the top Original Equipment Manufacturers (OEM) primarily from North America, Germany, and Japan that assemble final manufactured products. Japanese OEMs include Toyota, Nissan, Mazda, Honda, Mitsubishi, Suzuki, and Subaru (Fuji Heavy Industries). Down the supply chain, Tier-1 firms provide complex components directly to the OEMs, and in some instances they also collaborate in design activities. In 2019 there were around 400 Tier-1 suppliers in Mexico, all of them of foreign origin (Torres-Landa et al., 2019).

Further down the supply chain, Tier-2 firms provide value-added via parts and components that are distributed to Tier- 1 firms, and in some cases, they may also supply OEMs directly. At this level of procurement, there are about 400 companies in Mexico, with $30 \%$ of them being endogenous firms. As mentioned before, low shares of national ownership are more evident in the case of activities related to stamping, foundry, forging, and machining, where national content ranges from 25\% to 35\% (Ernst \& Young Global Li- 
mited, 2017; Torres-Landa et al., 2019). With the arrival of major Japanese OEMs, there has been interested by Japanese supplier firms to also establish in Mexico, by April 2017 there were 363 Japanese firms distributed between the Tier-1 and Tier-2 levels of procurement (AP JETRO, 2017). By 2019, around 1,200 Japanese firms were established in Mexico. Falck-Reyes and Guzman-Anaya (2018) mention that $80 \%$ of Japanese FDI is concentrated in the manufacturing industry and $57 \%$ in the transport equipment sector.

The Tier-3 level of the supply chain is related to engineered materials and services delivered primarily to Tier- 2 suppliers. At this level, it is estimated that there are around 2,290 auto parts suppliers. To acquire a full overview of the automotive industry, one must include companies focused on sales, distribution, and post-sales service to the production system. In total, there are close to 2,000 distribution agencies in Mexico. Tier-3 firms focused solely on automotive procurement are calculated at around 400 (Torres-Landa et al., 2019).

The Mexican automotive industry has positioned itself as an important producer worldwide and has shown to be essential for the internal economy. For example, in 2018 total global vehicle production was noted at $95.6 \mathrm{mi}$ llion, where Mexico contributed 4.1 million units, positioning the country as the $6^{\text {th }}$ overall producer. It is important to point out that a major part of the production of this industry is exported. From total production, $80 \%$ is sent overseas giving the country the $4^{\text {th }}$ overall exporter position worldwide (Falck \& Guzman, 2018). Between 2013 and 2018 the industry grew at annual growth rates of $5.6 \%$ in production, $4.4 \%$ in exports, and $19 \%$ in internal sales. By 2019 the growth trend was reverted, the country produced $3.9 \mathrm{mi}-$ llion units, with a drop of almost 3\%. Production further decreased by $36 \%$ from 2019 to 2020 according to data from the International Organization of Motor Vehicle Manufacturers amidst the Covid-19 pandemic (International Organization of Motor Vehicle Manufacturers [OICA], 2021).

Turning to the importance of the industry to the internal economy, in 2018 the automotive industry represented 3\% of Mexico's GDP and 18\% of manufacturing GDP. Also, the industry represented $27 \%$ of total exports and employed 875,000 workers (Falck \& Guzman, 2018). By 2019, the industry represented $3.8 \%$ of GDP contributing to 980,000 direct jobs (Mexico Business Publishing, 2020).

In terms of FDI, automotive investment flows represented $20 \%$ of total investment flows received by Mexico in 2019. It has been argued that $65 \%$ of 
total FDI received in Mexico is automotive related, where suppliers are mostly from the U. S. (19\%), Japan (18\%), and Germany (12\%). From the FDI flows received in the automotive industry, $46 \%$ were drawn by OEMs and $54 \%$ to the supporting auto parts industry (including tires) (Dziczek et al., 2017).

However, the industry's growth came to a halt in March 2020 due to the Covid-19 pandemic. Health concerns demanded the shutdown of nonessential economic activities where automotive manufacturing was affected. According to data from the Mexican Association of Automotive Distributors (AMIA in Spanish), between April 2019 and April 2020, automotive production fell by $98.8 \%$, automotive exports by $90 \%$, and internal automotive sales by $64.5 \%$. During July 2020, the production of vehicles increased $0.7 \%$, compared to the total number of units produced during the same month of the previous year; ${ }^{3}$ however, the improvement registered during June and July decreased significantly in August. The production levels recorded prior to the crisis cannot be reached and furthermore, the likelihood of counterbalancing the production loss of the first trimester is dim. ${ }^{4}$ The pandemic has brought about a new way of thinking about global production chains where a more regional approach with less focus and dependence on China is expected. Added to this, increasing economic tensions between the U. S. and China may deem as an opportunity for Mexican supplier firms to satisfy the increasing demand for regional parts and components. Also, the recent implementation of the United States-Mexico-Canada Agreement (USMCA) that replaces NAFTA will bring additional challenges for Mexican automotive firms. The USMCA establishes four rules of origin for light vehicles and auto parts: first, regional value content must be $75 \%$ (core parts $75 \%$, principal parts $70 \%$, complementary parts $65 \%$ ); second, $70 \%$ of steel and aluminum content must come from the NAFTA region; third, local content requirements establish that $40 \%$ of passenger vehicles and $45 \%$ of pick-ups must contain automotive parts and components manufactured by workers earning at least USD $\$ 16$ per hour by 2023; ${ }^{5}$ and the incorporation of the NAFTA core parts (7).

3. https://www.mms-mexico.com/articulos/industria-automotriz-en-mexico-en-2020-de-lareactivacion-a-la-recuperacion

4. https://www.eleconomista.com.mx/opinion/Industria-automotriz-perspectivas-al-cierredel-2020-20201004-0048.html

5. In this sense, from the calculations $25 \%$ and $30 \%$ must be of materials plus labor (base salary) plus transportation (cost of manufacture). Up to $10 \%$ may be considered for R\&D and IT activities. Up to $5 \%$ may be granted for OEMs that manufacture engines. 


\section{Japanese Automotive FDI in Mexico}

Focusing the analysis on Japanese FDI, historically, investment outflows increased as a result of the Plaza accord of 1985 and the appreciation of the Japanese Yen. During that time Japanese products were losing competitiveness in international markets and Japanese companies increased investment projects worldwide. As a result, outflows of Japanese direct investment increased during the 1980s primarily to Asia and the United States seeking alternative markets for Japanese exports (see Figure 2). This upward trend continued, making Japan one of the main investors worldwide.

Figure 2

Outward Japanese Foreign Direct Investment Flows, 1980-2019

TOTAL JFDI

(OUTWARD, MDD)

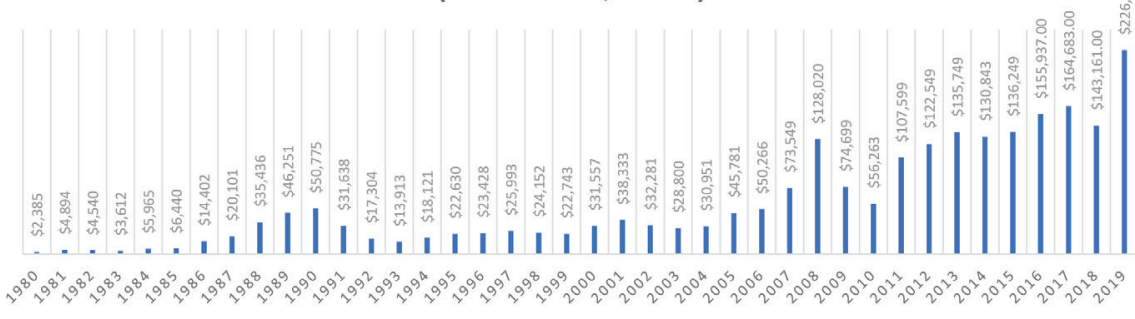

Source: Author's own elaboration with data from UNCTAD (2020).

NAFTA was one of the key factors that motivated Japan to sign an Economic Partnership Agreement (EPA) with Mexico in 2004 (the first EPA for Japan with a western country), where Japanese companies gained access to North American markets. Also, by signing the EPA Japanese products were granted access to the Mexican market enjoying the preferential treatment, as well as protection for Japanese investment projects, and gained access to partake in public government bids for investment projects. For the Mexican side, the EPA represented a trade and investment diversification strategy in Asia, expecting to attract investment flows to different economic sectors and to export Mexican products, mainly in the agricultural sector. The Mexican government also anticipated from the EPA to import technological products 
and for Mexican suppliers to enter Japanese production chains increasing the overall productivity levels of certain key industries.

For the case of Japanese investment in Mexico, FDI flows increased significantly after the implementation of the EPA in 2005 and more noticeably since 2012. As Japanese FDI has received national treatment since the EPA was signed, it has shown a powerful impulse, like its US and European counterparts (Falck Reyes, 2012). Figure 3 compares Japanese FDI flows to Mexico from the Japan External Trade Organization (Japan External Trade Organization [JETRO], 2019). The graph shows that FDI flows from Japan escalated after 2011, corresponding to the years of the arrival of Japanese automotive assemblers and suppliers to Mexico. Specifically, in 2003, total Japanese FDI flows to Mexico were noted at \$139 million U. S. dollars (USD) and this figure jumped to USD $\$ 1,329$ million by 2015. In total between 2003 and 2015, total Japanese investment amounts to 22.95 billion USD. Also, by 2009 it was estimated that around 400 Japanese firms were established in Mexico and this figure increased to over 1,000 firms by 2016 (Salas, 2016). Similarly, the number of Japanese nationals living in Mexico went from a little over 6,000 in 2008 to over 9,000 in 2015. This sharp increase has been followed by an important growth in sales and employment in Japanese companies established in Mexico. Comparing quarters in 2015 and 2016, sales from Japanese companies grew $15 \%$ and employment $12 \%$ reflecting a favorable business environment for Japanese multinationals (Ministry of Economy, Trade, and Industry [METI], 2017). This has been also reflected in the overall Japanese FDI attraction index published by the Japan Bank for International Cooperation, where Mexico occupied the $12^{\text {th }}$ position in 2011 and moved to the $6^{\text {th }}$ position in 2015. This index ranks the countries in terms of business development prospects for Japanese companies over the medium term (Japan Bank for International Cooperation [JBIC], 2016). 
Figure 3

Total Japanese FDI Flows to Mexico, 1995-2019

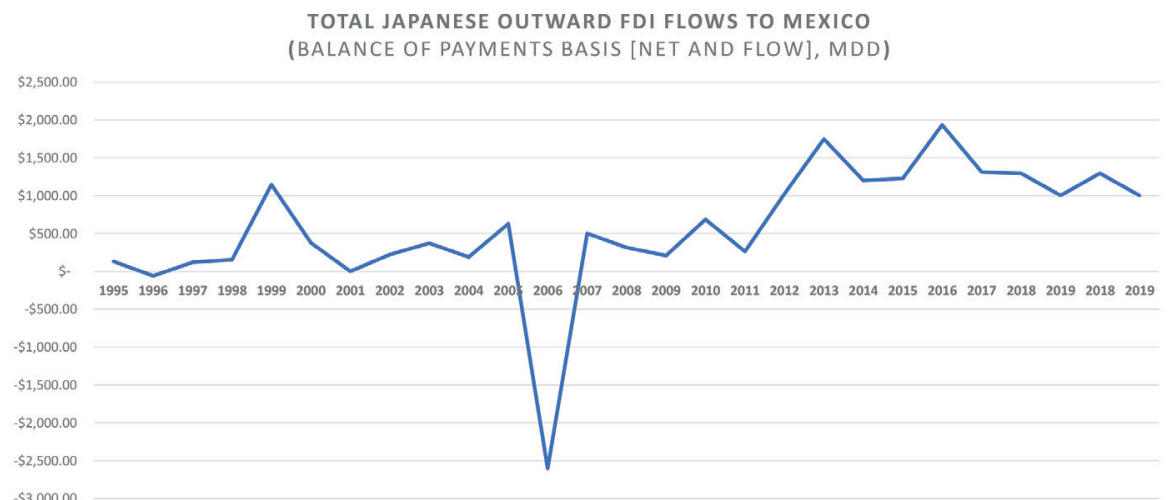

Source: Authors' calculations with information from JETRO (2019).

Since the EPA came into force in 2005 Japanese FDI flows have increased and concentrated in the automotive industry. For example, between 2003 and 2013 Japanese FDI flows to Mexico grew at an annual average growth rate of over $20 \%$, and over $70 \%$ of this investment concentrated in the automotive industry. There are expectations that future investment flows continue this upward trend. For example, Toyota arrived in Celaya, Guanajuato in 2016 to produce the Tacoma model and a SUV with the forecast of 2,000 direct jobs. It can be noted that the Japanese assemblers that have moved production to Mexico will increasingly rely on the presence of a supply network throughout North America, disposing of the logistical disadvantage of overseas procurement of parts and components (Dziczek et al., 2017).

The arrival of Japanese automotive producers and growing interest in locating in Mexico is explained by several factors in addition to the EPA. First, Mexico's strategic location as a production hub that provides access for exporting to the North American and South American markets, specifically Canada, the U. S., and Brazil. Second, a growing internal market for automotive products has also attracted Japanese firms. Third, the presence of functional infrastructure that provides the elements for Japanese firms to establish a production network. Fourth, the presence of competitive production costs; especially labor costs with high qualifications have contributed to the arrival of automotive firms. Finally, Japanese firms also value a solid political sys- 
tem with favorable labor conditions and stable economic and fiscal policies (Secretaría de Economía, 2017).

Figure 4 displays the geographical distribution of 396 Japanese Tier-1 and Tier-2 automotive supplier firms at a state level in 2020. The map shows that Japanese firms seem to agglomerate in the center and northern parts of Mexico. The southern part of the country displays no presence of Japanese firms. Lower levels of development characterize the southern part of Mexico, while the northern and central regions have traditionally concentrated higher levels of economic development, communication, financial and banking services, and transportation infrastructure making it more desirable to locate investment projects.

\section{Figure 4}

The distribution of Japanese automotive suppliers Mexico

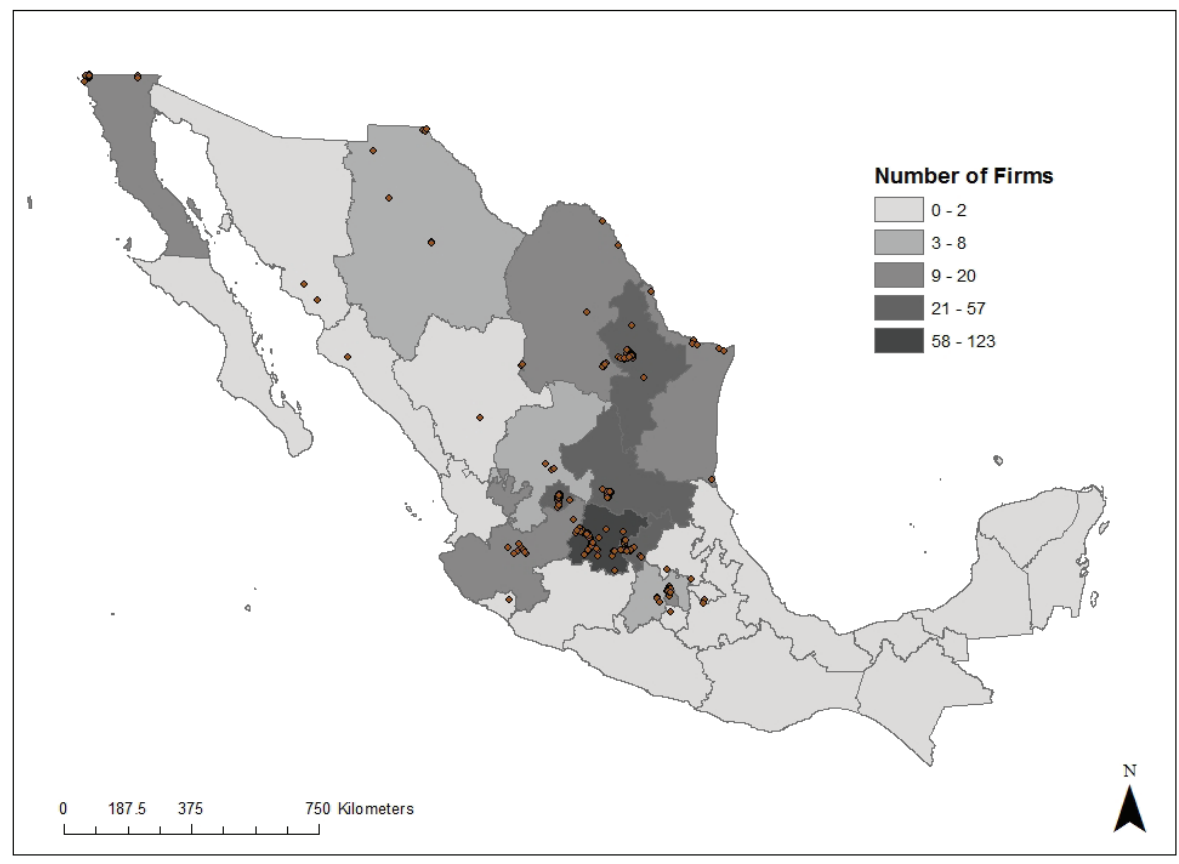

Source: Author's calculations based on data from Toyo Keizai (2015, 2016, 2020).

It is important to point out that despite pressure from the Covid-19 pandemic and the new labor regulations under the USMCA, Japanese multinational 
automobile manufacturers have expressed their willingness to maintain their operations in Mexico. This means that firms in certain cases will either pay the wage increase of USD $\$ 16$ per hour or pay the tariffs imposed. Nakayama and Asayama (2020) mention that auto parts producers located in Mexico such as Keihin and Piolax have already increased their hourly wage to USD $\$ 16$ per hour for factory workers (three times the average rate of auto part factories in Mexico). The main reason is the high cost of moving production, especially for firms that had recently located in Mexico and had not yet recovered their investment. In the end, the higher production costs will be passed on to consumers in higher prices and reduced competitiveness and sales in the region.

\section{Literature Review}

The empirical literature suggests that the regional distribution of Japanese FDI seems to be influenced by factors associated with regional demand, regional production costs, regional policies, regional agglomeration economies, regional infrastructure, and regional strategic location. However, previous studies highlight the fact that Japanese FDI seems to follow an agglomeration distribution in the host country, especially for the case of the automotive industry, where firms benefit from the proximity between assemblers and suppliers (Smith \& Florida, 1994).

An important factor in the location decision of Japanese automotive suppliers is the location of affiliated automotive clients. Japanese FDI seems to show an agglomeration preference in the automotive industry where the organizational and productive structure of the manufacturing process favors proximity between firms that form part of the supply chain (Asanuma, 1989). This becomes more noticeable for small and medium-size suppliers that invest abroad to follow a major buyer of their parts and components (Belderbos \& Carree, 2002). Automotive suppliers seem to choose their locations abroad following the automotive assemblers with whom they have relationships in Japan (Hayashi, 2012; Martin, Swaminathan \& Mitchell, 1998; Smith \& Florida, 1994).

Kondo (2018) analyses the international sourcing patterns of export-platform foreign affiliates from a new approach: an extension of the production function estimation in the total factor productivity literature. The author decomposes production into country-by-country transactions and decomposes 
intermediate inputs into country-by-source purchases. The linkages between input and output are then calculated as the intermediate input elasticity of exports between countries. The study shows that international affiliates in Mexico derive input from third countries, including the US and Canada, rather than from Japan and Mexico, from the Japanese export network.

Wakasugi (2005) argues that a vertical form of manufacturing fragmentation mechanism is followed by Japanese firms that invest abroad, where affiliate firms extend the Japanese production networks. In this sense, if a network-related business invests overseas, other companies also invest in the recipient country to continue to provide the required inputs. The agglomeration also favors the specialized preference for amenities (e. g. schools, restaurants, etc.) and facilitates the establishment of just-in-time delivery and control systems, and the development of long-term supplier-client relationships (Head et al., 1995; Reid, 1995).

Empirically, studies have used location shares of Japanese FDI as a proxy for Japanese firm agglomeration (Cheng \& Stough, 2006). Belderbos and Carree (2002) employ three different measurements of agglomeration (industry, Japanese, and Keiretsu). Smith and Florida (1994) use a straight-line distance between an automotive assembler and the nearest county with presence of Japanese suppliers. Zhou et al. (2002) account for agglomeration by the total number of Japanese subsidiaries in a city in a previous year. For the case of Japanese firms, the agglomeration hypothesis in most studies turns out to be positive and statistically significant in determining the location of Japanese FDI. These measurements are regarded in the literature as "mesoeconomic" measures of concentration. Arbia, Espa, and Giuliani (2016) argue that mesoeconomic measures of concentration fail to take into consideration the spatial nature of the data and are insensitive to permutations of the spatial units. In this sense, it is recommended to use methods that consider the spatial dependence such as Moran's I Index or the Average Nearest Neighbor.

Belderbos and Carree (2002) and Wakasugi (2005) highlight that Japanese firms seem to follow other Japanese firms in the same industry. Aoki (1990) mentions that Japanese firms replicate the productive and organizational structure employed in Japan that favors the preference for agglomerated production networks between assemblers and suppliers of parts and components.

For the case of Mexico, several studies support the agglomeration hypothesis. Jordaan (2012) finds that FDI firms pertaining to the manufacturing industry have concentrated in a group of states within Mexico that registers 
agglomeration of economic activity, suggesting that the location of foreign firms is influenced by the presence of regional agglomeration economies. Furthermore, the author finds that agglomeration economies do have an inter-regional reach and those agglomerations of Mexican manufacturing companies and foreign owned firms have a positive impact on the probability that the region is favored by new FDI firms. Kakihara and Guzman (2014) show an agglomeration preference for Japanese automotive suppliers located in Aguascalientes and Guanajuato. Firms seem to follow major clients and locate near other competing firms to reduce transaction costs and uncertainty in the new investing country. Similarly, Guzman-Anaya (2015; 2017; 2018) shows the importance of agglomeration of Japanese firms in Mexico. The studies employ econometric techniques to measure spatial agglomeration and suggest that the variable is a determinant factor of Japanese firm location in Mexico.

With the previous information presented, there has been an important increase in Japanese FDI to Mexico since the EPA; however, little research has been conducted to analyze the spatial distribution of this type of investment. The maps presented in figures 4 and 5 provide a visual representation of the data, however other research methods are necessary to confirm an agglomeration preference for Japanese automotive FDI in Mexico. Therefore, it is necessary to measure the agglomeration behavior of Japanese automotive firms arriving in Mexico. The methodology proposed employs spatial dependence measurements of concentration to confirm the agglomeration preference of Japanese Tier-1 and Tier-2 automotive supplier firms in Mexico.

\section{Methodology}

To conduct the analysis there is a requirement to use disaggregated firm-level data from Japanese automotive companies in Mexico. For this case, the data originates from various sources. Primarily from the Kaigai Shinshutsu Kigyou Souran-Kuni Betsu (Japanese Overseas Investments - by country), an annual survey of overseas activities from Japanese firms all over the world published by Toyo Keizai. The Toyo Keizai publication lists virtually the total population of Japanese foreign subsidiaries by the host country and has been widely employed in previous studies investigating the spatial distribution and location choices of Japanese firms overseas (Yamawaki, 1991).

For this study, the Toyo Keizai directories 2014, 2015, 2016, and 2020 were consulted to create a unique database with Japanese automotive 
suppliers in Mexico. As noted earlier, the directory compiles information on the overseas activities of Japanese firms all over the world (Keizai, 2016). Complimentary information was gathered from Japan's Chamber of Commerce and Industry directory 2015. This directory is published on an annual basis. It includes information regarding company name, address, and contact information (telephone, fax, and email) (Cámara Japonesa de Comercio e Industria de México, 2016). Finally, data were also consulted from the National Registry of Foreign Investment from Mexico's Secretariat of Economy (Secretaría de Economía, 2020). In total 396 Japanese tier-2 automotive supplier firms were identified; afterward, the registered address was verified through the company's website and once it was confirmed, each firm was georeferenced in a spatial database.

The concept of concentration has been investigated in various ways. One approach is related to the non-spatial properties of the data. This is the traditional way of measuring concentration by analyzing the spatial distribution of economic activities and looking at the scattering of economic agents within geographical areas such as administrative units, municipalities, states, or regions in what the literature calls the "mesoeconomic" approach. The methods included in this approach incorporate a model of spatial concentration based on Gini's locational coefficient that was used to measure the concentration pattern of U. S. industries (Krugman, 1991). Another model consists of indexes that model location choice and sectoral concentration by measuring industrial concentration (Maurel \& Sedillot, 1999). The problem with mesoeconomic measures of concentration is that they fail to consider the truly spatial nature of the data and assume that the observations are generated through the traditional sampling model of independence and are insensitive to any permutation of spatial units (Arbia, Espa \& Giulani, 2016).

An approach that deals with this shortfall are related to the idea of polarization of economic agents in space. Methods that consider spatial dependence include "Moran's I index", Getis-Ord Gi", and the "Average Nearest Neighbor Index".

Moran's I index is used as a measure of spatial dependence. This index is generally used in the empirical analysis to test for spatial correlation.

Moran's I is defined as:

$$
I=\frac{N}{S_{0}} \frac{\sum_{i=1}^{N} \sum_{j=1}^{N} w_{i, j} z_{i} z_{j}}{\sum_{i=1}^{N} z_{i}{ }^{2}}
$$


where $\mathrm{zi}$ is the deviation of the variable $\mathrm{xi}$ from the sample mean ( $\mathrm{xi}-\overline{\mathrm{x}})$; $\mathrm{w}(\mathrm{i}, \mathrm{j})$ are the spatial weights taken from the weights matrix $(\mathrm{W}) ; \mathrm{N}$ is the sample size and S0 is the sum of spatial weights. Additionally, S0 may be defined as:

$$
S_{0}=\sum_{i=1}^{N} \sum_{j=1}^{N} w_{i, j}
$$

Moran's I is distributed under a standardized normal distribution for large samples, where the statistic can be calculated as:

where:

$$
Z_{I}=\frac{I-E[I]}{\sqrt{V[I]}} \sim N(0,1)
$$

$$
\begin{gathered}
E[I]=-1 /(N-1) \\
V[I]=E\left[I^{2}\right]-E[I]^{2}
\end{gathered}
$$

A limitation from Moran's I is that it evaluates global dependence in all regions included but it is not able to present the presence of local cluster patterns. To measure the presence of regional clusters, local indices may be computed. In this case, it is possible to compute Moran's local index, also known as Local Indicator of Spatial Association (LISA). This statistic is able to confirm spatial dependence for each region in the data (Romero \& Andrés-Rosales, 2014). The LISA index is defined as:

$$
I_{i}=\frac{z_{i}}{s_{i}^{2}} \sum_{j=1, j \neq i}^{N} w_{i, j} z_{j}
$$

where $\mathrm{Si}^{\wedge} 2$ may be defined as:

$$
S_{i}^{2}=\frac{\sum_{j=1, j \neq i}^{N} w_{i, j}}{N-1}-(\bar{x})^{2}
$$

Similarly to Moran's I Index, the LISA index also follows a standardized normal distribution for large samples. The statistic may be calculated as:

$$
Z_{I_{i}}=\frac{I-E\left[I_{i}\right]}{\sqrt{V\left[I_{i}\right]}} \sim N(0,1)
$$


where:

$$
\begin{gathered}
E[I]=-\frac{\sum_{j=1, j \neq i}^{N}}{N-1} \\
V[I]=E\left[I^{2}\right]-E[I]^{2}
\end{gathered}
$$

If the LISA index shows a statistically significant and positive high value, this reflects a cluster in region $i$ with presence of similarly high values; on the other hand, a statistical significant and negative value would reflect clustering of similar low values (Romero \& Andrés-Rosales, 2014).

To employ Moran's, I in the analysis the first step was to sum all Japanese automotive suppliers in Mexico within the municipality boundaries where each firm was located. This permitted the creation of a polygon with the counts of Japanese firms for all municipalities in Mexico. Therefore, the presence of spatial autocorrelation was tested in terms of municipalities with the presence of Japanese Tier-1 and Tier-2 supplier firms.

The nearest neighbor index is one of the oldest distance statistics. Developed in the 1950s by two botanists, Clark and Evans (1954) to conduct fieldwork, it has become a widely used tool in different fields of research. The average nearest neighbor can be used to quantify and compare the spatial distribution of a variety of features within a fixed study area. It is a useful tool to measure and monitor changes over time, as it allows observing spatial clustering for a certain type of business or industry within a fixed study area throughout a determined amount of time.

Average nearest neighbor is a measure of the distance between each centroid on a feature and its nearest neighbor centroid location, followed by a calculation of the average of all the distances of the nearest neighbors. Whenever the average distance is greater than the hypothetical random distribution, the features are considered dispersed. With the expected average distan ce being based on a hypothetical random distribution with the same number of features covering the same total area, the average nearest neighbor ratio is calculated as the observed average distance divided by the expected average distance:

The ratio of the average nearest neighbor is given as:

$$
A N N=\frac{\bar{D}_{O}}{\bar{D}_{E}}
$$


Where $\bar{D}_{o}$ is the observed mean distance between each feature and its nearer neighbor:

$$
\bar{D}_{O}=\frac{\sum_{i=1}^{n} d_{i}}{n}
$$

And $\bar{D}_{E}$ is the expected mean distance for the features given in a random pattern:

$$
\bar{D}_{E}=\frac{0.5}{\sqrt{n / A}}
$$

where $d_{i}$ equals the distance between the feature $i$ and its nearest neighboring feature, $n$ corresponds to the total number of features, and $A$ is the area of a minimum enclosing rectangle around all features, or represents an area specified by the user as Area Value.

The occurrence of some differences in the index by chance is expected. Clark and Evans (1954) proposed a Z-test to indicate whether the mean distance of the observed nearest neighbor was significantly different from the mean random distance. The test between the observed distance of nearest neighbor and that expected from a random distribution is given by the following equation:

$$
z=\frac{\bar{D} o-\bar{D}_{E}}{S E}
$$

where the standard error of the mean random distance is approximately given by:

$$
S E=\frac{0.26136}{\sqrt{n^{2} / A}}
$$

where $A$ is the area of a region and $n$ represents the number of points. The equations (4) \& (5) are commonly used to test the average nearest neighboring distance.

If the index for the average nearest neighbor ratio is less than 1 , the pattern demonstrates clustering; if the index is greater than 1 , the results indicate dispersion. The average nearest neighbor method is sensitive to a small modification in the land distribution can result in dramatic changes in the computation. 
The equations ( 1 ) used to calculate the average nearest neighbor distance index and the $\mathrm{z}$-score (4) assume that the points being measured are free to locate anywhere within the area of interest (where there are no barriers, and all the features are located independently of one another). The p-value is a numerical approximation of the area under the curve for a known distribution, limited by the statistic test.

Spatial statistics calculates the Getis-Ord Gi* statistic (pronounced G-istar) for each feature in a dataset through the hot spot analysis. The resultant z-scores and p-values show either high or low values of the spatial cluster for the features analyzed. Each feature is observed within the context of neighboring features where a high value reported by a feature is interesting but may not necessarily mean that is a statistically significant hot spot; to be one, a feature should have a high value and should also be surrounded by other features with high values as well. The local sum for a feature and its neighbors is proportionally compared to the sum of all features. In the case where the local sum differs from the expected local sum and that difference is too large to be a random result, it results in a statistically significant $\mathrm{z}$-score.

The Getis-Ord local statistics is calculated as follows:

$$
G_{i}^{*}=\frac{\sum_{j=1}^{n} w_{i, j} x_{j}-\bar{X} \sum_{j=1}^{n} w_{i, j}}{S \sqrt{\left[\frac{\left[\sum_{j=1}^{n} w_{i, j}^{2}-\left(\sum_{j=1}^{n} w_{i, j}\right)^{2}\right]}{n-1}\right.}}
$$

where $x_{j}$ is the attribute value for feature $j, w_{i, j}$ is the spatial weight between feature $i$ and $j, n$ is equal to the total number of features and:

$$
\begin{gathered}
\bar{X}=\frac{\sum_{j=1}^{n} x_{j}}{n} \\
S=\sqrt{\frac{\sum_{j=1}^{n} x_{j}^{2}}{n}-(\bar{X})^{2}}
\end{gathered}
$$

The $G_{i}{ }^{*}$ statistic is a z-score, so no further calculations are required. 


\section{Results}

The results from the Moran's I index are presented in figure 5 and suggest the presence of spatial autocorrelation. Specifically, the positive value from Moran's I index indicates that municipalities with a high (or low) presence of Japanese Automotive firms are grouped with other municipalities with a high (or low) number of Japanese firms, suggesting the presence of agglomeration. The results are statistically significant at the $99 \%$ confidence interval meaning that there is less than $1 \%$ likelihood that the grouping of firms would be the result of random chance.

\section{Figure 5}

Moran's I Index Results

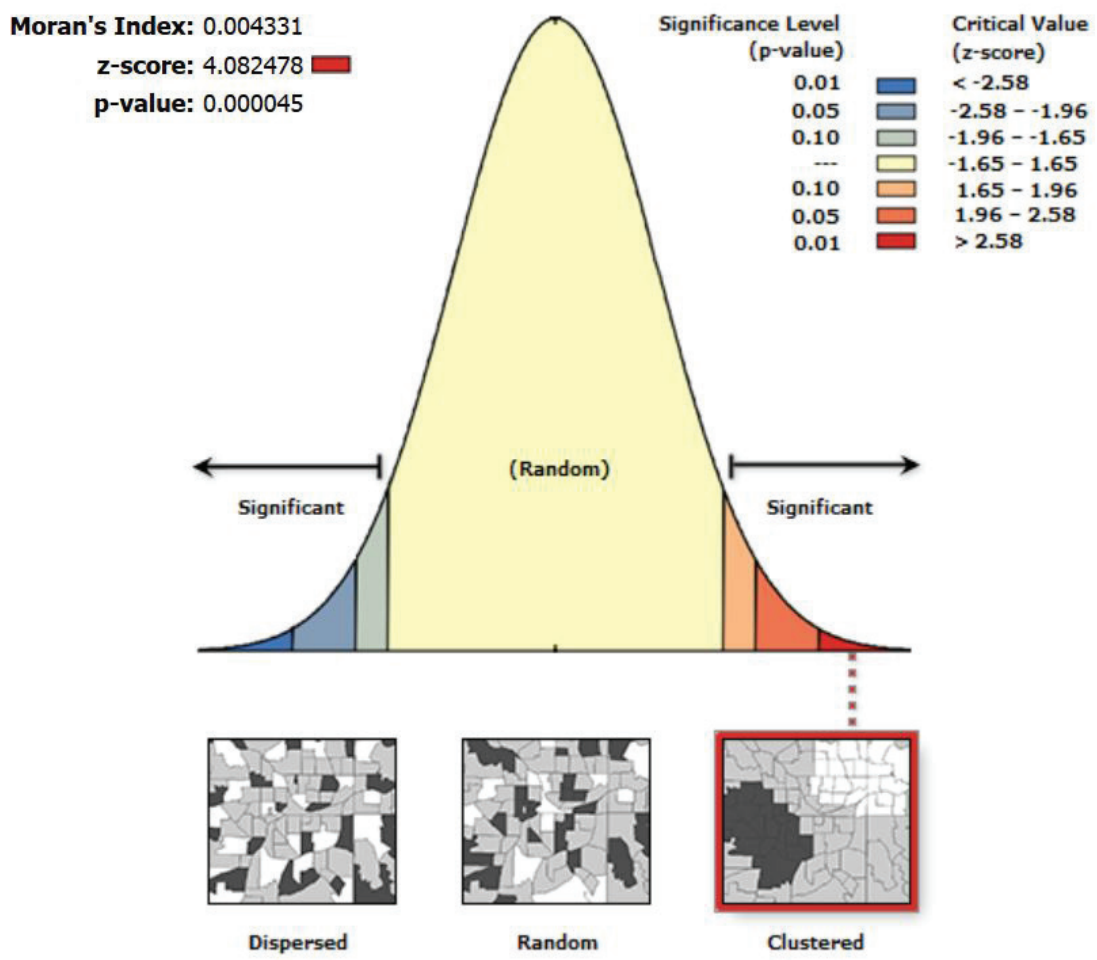

Notes: Results were generated using the Esri Arcmap 10.1 software. 
As part of the analysis, following Moran's I results, the Average Nearest Neighbor method was also employed to conduct a similar pattern analysis making use of the point data generated in the spatial database for Japanese Automotive suppliers in Mexico. The results are presented in figure 6 and advise a clustering type of the point data that is statistically significant at the $99 \%$ confidence interval. In other words, this suggests that there is less than $1 \%$ likelihood that the clustering of firms observed would be the result of random chance.

\section{Figure 6}

\section{Average Nearest Neighbor Results}

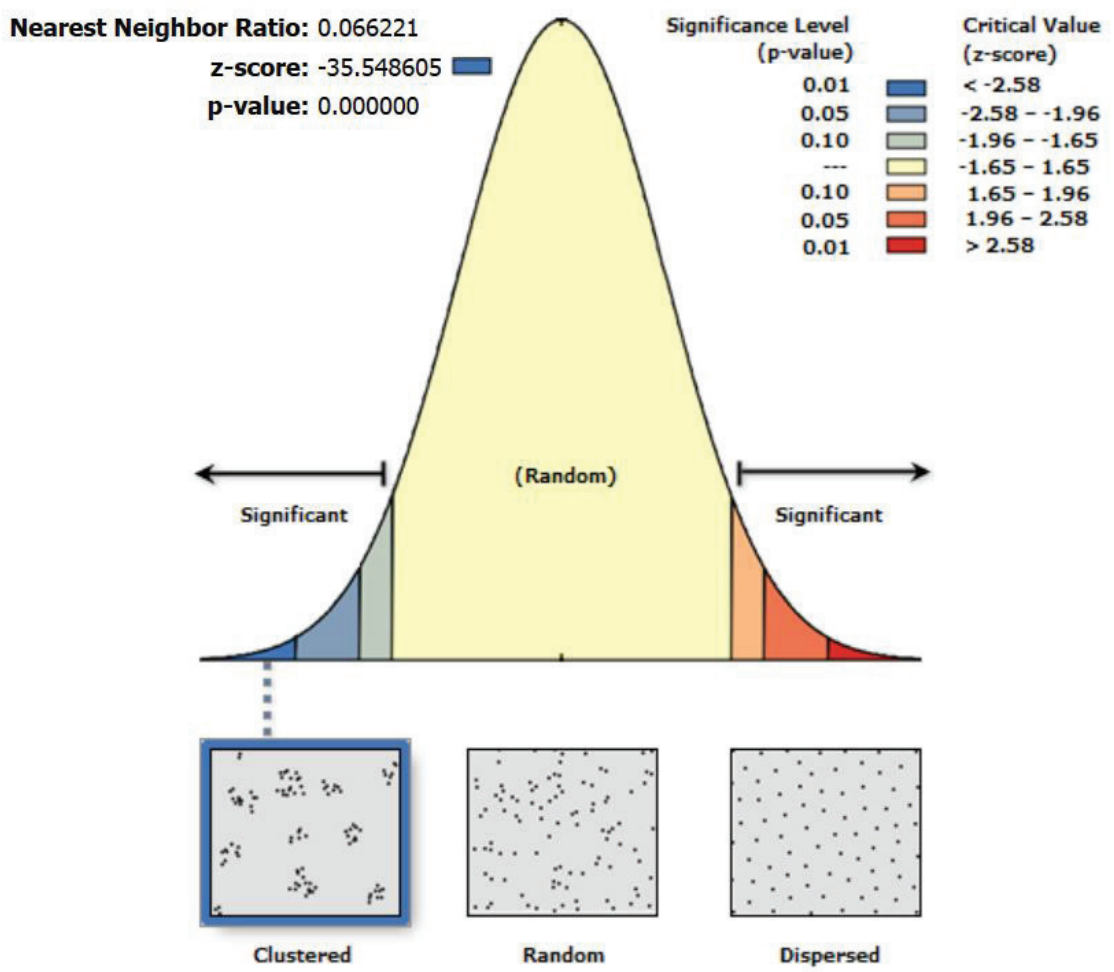

Notes: Results were generated using the Esri Arcmap 10.1 software. 
Figure 7

Hot Spot Analysis Getis-Ord Gi* Results

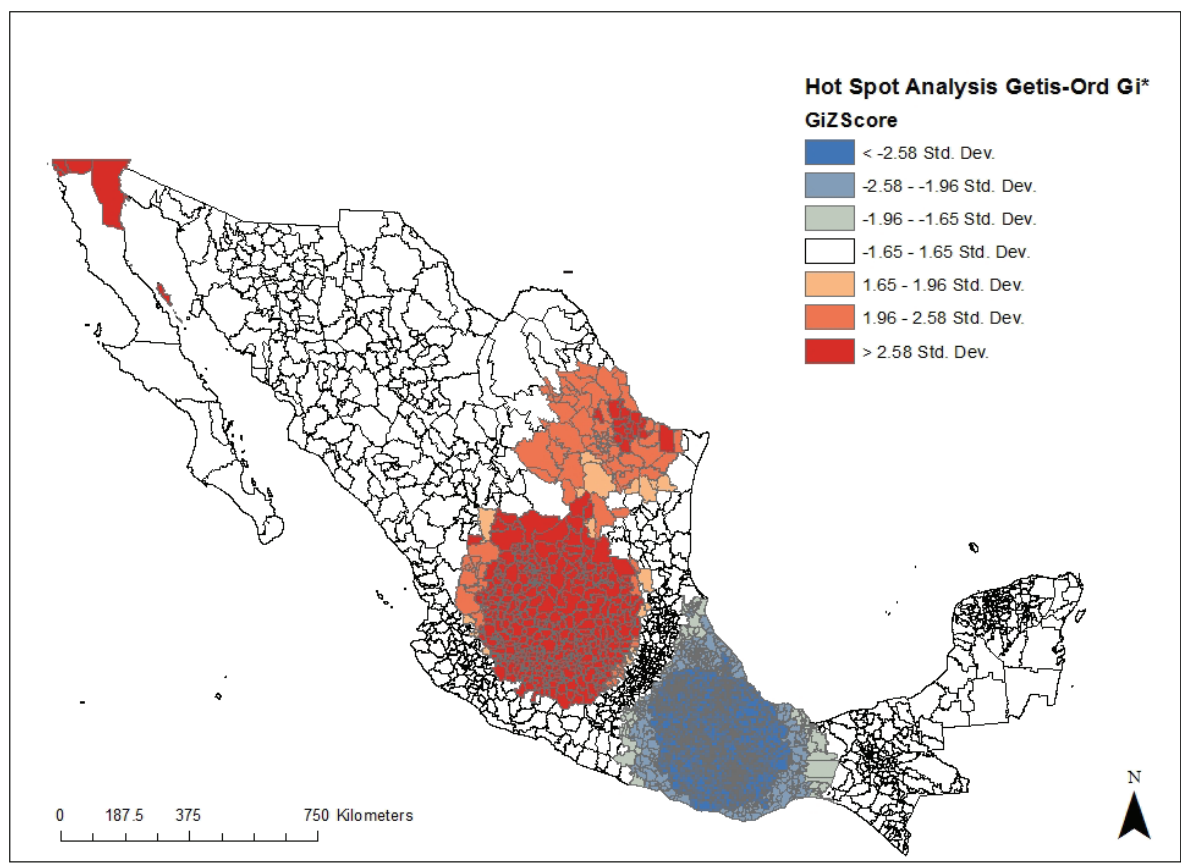

Notes: Results were generated using the Esri Arcmap 10.1 software.

The Getis-Ord $\mathrm{Gi}^{*}$ analysis shows significant spatial clusters of high values (hot spots) and low values (cold spots). The results are presented in figure 7 and indicate spatial clustering of high values in the western and northern parts of Mexico and clustering of low values in the southern regions. The $z$-scores for those regions reject the null hypothesis of random distribution and indicate that the clustering is not due to chance.

From the Moran's I index, the Average Nearest Neighbor Index and GetisOrd Gi* results, the analysis presented has shown that Japanese automotive supplier firms in Mexico follow an agglomeration pattern, that coincides with what has been reported for other host countries (Belderbos \& Carree, 2002; Cheng \& Stough, 2006; Smith \& Florida, 1994; Zhou et al., 2002). Finding spatial autocorrelation indicates that municipalities that become attractive for the location of Japanese firms or fail to do so are grouped with other mu- 
nicipalities with high or low presence of these types of firms, indicating the presence of agglomeration. Also, by making use of unique firm data generated in the spatial database the findings show a clustering type of the point data confirming that Japanese firms follow this type of industrial organization preference in Mexico. The study has employed methods that account for spatial dependence in the data and advance the current literature on Japanese FDI agglomeration of automotive suppliers.

\section{Conclusion}

The choice of studying Japanese automotive suppliers and their location decisions in Mexico was motivated by several factors. First, Mexico transitioned from import substitution to an export promotion development strategy where FDI became an important source of financing, and high expectations were set on the spillover effects for the local economy. In this sense, the theoretical models suggest positive externalities to endogenous agents, but empirical literature is still divided on this topic. A possible explanation for this absence of consensus might be rooted in the fact that FDI has been treated as a whole, mainly researched without separating the origin of the investment. The source of the investment seems to matter since different countries follow particular forms of organization and relate to the local economy in various ways.

Second, Japanese FDI flows to Mexico have increased since the signing of the Mexico-Japan Economic Partnership Agreement in 2005 and most investment has been concentrated in the automotive industry. This industry provides an interesting area for research since Japanese firms seem to locate in the host country following a proximity preference between suppliers and assembling firms. Also, most research on FDI location distribution for the case of Mexico has been conducted without considering the nationality of the investor, failing to identify disparities that might arise from different sources of investment. Previous studies on the location choices of Japanese FDI have focused on the case of China or the U. S. with scarce information for other countries, limiting the understanding of the location preferences for Japanese firms. Finally, understanding and measuring the agglomeration of Japanese automotive suppliers for the case of Mexico augments this body of literature and new findings provide information for local governments that design policies to influence the location distribution of Japanese investment. 
From previous theoretical and empirical work, it is argued that Japanese firms tend to agglomerate in the host country incentivized by factors regarding regional demand, regional production costs, regional policies, regional agglomeration economies, regional infrastructure, and regional strategic location, and this behavior is more evident for the case of automotive firms. The argument behind agglomeration is that concentration increases the pool of skilled and specialized workers, promotes the development of specialized inputs, and facilitates the presence of technological and productivity spillovers among firms. This also has been argued for the automotive industry, where firms benefit from the proximity between assemblers and suppliers.

The study created a unique spatial database to analyze the geographical distribution of Japanese automotive supplier firms using data from various sources. First, a visual representation of the data showed that Japanese firms appear to agglomerate in the center and northern parts of Mexico, in regions that are characterized to have higher levels of economic development, more advancement in infrastructure and production services, and therefore more attractive to foreign investment projects. Also, the agglomeration seemed to favor proximity between automotive suppliers and assemblers. This information presented an overview of the agglomeration phenomena, but a more rigorous measure of spatial dependence was employed to confirm this type of behavior for Japanese firms in Mexico.

The analysis employed a unique database using disaggregated firm-level data from Japanese automotive suppliers in Mexico. In total 396 Japanese automotive Tier-1 and Tier-2 supplier firms were identified, with a valid address making it possible to generate a georeferenced spatial database. The information was compiled from the Toyo Keizai 2014, 2015, 2016, and 2020 directories, Japan's Chamber of Commerce and Industry directory 2015, and from the National Registry of Foreign Investment from Mexico's Secretariat of Economy (2020).

The traditional approach to measure spatial concentration is related to the non-spatial properties of data, which is known as the "mesoeconomic" approach. However, a shortcoming from this angle is that it fails to consider the spatial nature of the data and assumes that observations are gathered through the traditional sampling model of independence, making them insensitive to any permutation of spatial units. The approach followed in this study to measure spatial concentration deals with this shortfall and is related to the idea of polarization of economic agents in space. Specifically, 
the methods employed included "Moran's I index", Getis-Ord Gi*, and the "Average Nearest Neighbor Index". Moran's I index provides a measurement of spatial autocorrelation, the Nearest Neighbor Index evaluates clustering or dispersion patterns in the data, and Getis-Ord Gi* shows the presence of hot or cold spots in the units of analysis.

The results obtained from the Moran's I index offer the presence of spatial autocorrelation. A positive and statistically significant value from Moran's I index suggests that municipalities with high (or low) presence of Japanese Automotive firms are crowded with other municipalities with high (or low) number of Japanese firms. The results provide evidence of firm agglomeration. Turning to the results from the Average Nearest Neighbor method, the findings suggest a clustering type of the point data that is statistically significant at the $99 \%$ confidence interval, meaning that there is less than $1 \%$ likelihood that the clustering of firms observed would be the result of random chance. The agglomeration of Japanese FDI hypothesis is also confirmed with the Getis-Ord $\mathrm{Gi}^{*}$ analysis, which indicated significant spatial clusters of high values (hot spots) in the western and northern parts of Mexico and low values (cold spots) in southern regions. The results are statistically significant indicating that the clustering of the point data is not due to chance.

From the Moran's I index, the Average Nearest Neighbor Index and the Getis-Ord Gi* results, the analysis has provided evidence that Japanese automotive supplier firms in Mexico agglomerate and this is consistent with findings for other countries.

Specifically, municipalities that are successful in attracting Japanese firms are grouped with other municipalities with the presence of Japanese firms, indicating the presence of agglomeration. To confirm agglomeration and by making use of point data generated in the spatial database, the findings reveal a clustering pattern of the point data, confirming Japanese firms follow this type of industrial organization preference in Mexico. From the results obtained, it seems relevant to policymakers to provide favorable conditions for the development of the automotive industry and the inherent supply chain. The agglomeration of firms may in turn bring positive externalities to horizontally and vertically related firms. Further research is encouraged in this area.

The results follow those reported by Smith and Florida (1994), Belderbos and Carree (2002), Cheng and Stough (2006), Zhou et al. (2002). The research has advanced the current literature by providing empirical evidence 
of the agglomeration of Japanese FDI hypothesis using automotive Tier-1 and Tier-2 supplier data and employing research methods that capture the a-spatial nature of the data accounting for spatial dependence. However, future research should focus on the positive and negative externalities from such agglomeration, the inclusion of local firms in the Japanese production chains, and the understanding of the supplier-client relationships from the agglomeration around core firms (keiretsu-type of relationships).

From the overview of Mexican automotive industry, and the case of Japanese FDI, it is clear that one of the main challenges for Mexico, as a host country, is how to incorporate Small and Medium Enterprises in the automotive supply chain. Despite the clear renewed interest in Mexico's automotive industry and the industry's development there are still clear challenges ahead, especially for the case of local firms and human capital. It has been observed that OEMs, particularly Japanese assemblers install in a host country making use of their home country supply network, limiting the possibilities of local firms to incorporate in the value chain and in some cases crowding out investment opportunities.

From the local supplier's side, to truly compete in an industry that is characterized by forging trust and long-term relationships, firms must improve quality to meet with international standards, or at least to the industry's requirements. This has been the greatest obstacle for local firms to enter the automotive industry's value chain. Also, local firms must transition from merely manufacturing activities to more value-added innovation and design enterprises. In a country where R\&D endeavors are not promoted (Mexico's public investment in R\&D is $0.6 \%$ of GDP, while other OECD countries invest over $4 \%$ of GDP) (Global Business Reports, 2016) this is also a major challenge for local firms. For domestic firms, also the access to finance becomes an entry barrier to the industry. Mexican firms suffer difficulties and high costs to access credit in comparison with foreign competitors, hampering their growth potential. In this sense, local governments through public policies may implement concrete actions to provide financial support for struggling firms. As it has been noted, the main opportunities arise in the Tier- 1 and Tier-2 levels of procurement, where almost more than half of the inputs are still being imported.

Another major challenge is observed in human capital development. Currently, the industry has worked jointly with development agencies from Mexico (Amexcid) and Japan (JICA) and academic institutions (Technological 
schools such as Conalep) to ensure the sufficient supply and technical skills from technicians and engineers given the increasing demand for skilled workers. However, these efforts have proven to not be sufficient since growing automotive locations are experiencing labor shortage and high labor rotation, proving that universities and technological centers are failing to meet with the requirements of a constantly evolving industry. In this sense, in the short-term human capital development programs from the employing firms might help reduce training shortfalls and help with labor turnover rates. In the medium-term, universities must offer specialized programs tailored to the industry's requirements with learning-by-doing and hands on experience training. In the long-term, the focus must be on human capital qualifications for R\&D and innovation activities. It is estimated that around 12,000 engineers graduate yearly from public and private academic institutions and this labor force might be better employed and developed by creating engineering and design centers in Mexico. It is suggested that synergies should be encouraged between all levels of government (federal, state, and municipal), academic institutions and foreign and local firms to increase competitiveness and promote the development of the automotive industry.

Under an era of uncertainty glooming over Mexico's economy given a possible change in direction towards a more protectionist trade policy from the U. S. and the world economy, it becomes pertinent for the Mexican public and private sectors to strengthen the internal economy and diversify trade and investment relations with other parts of the world. In this sense, the Latin America and Asia Pacific regions represent opportunities with growing and dynamic scenarios. The U. S. has proposed trade policies that may risk global economic integration and multilateralism as instruments for poverty alleviation and global economic growth (Granados, 2016). For the specific case of the automotive industry, the possible scenario of changes in the tariff structure between Mexico and the U. S. might impede automotive OEMs to deliver affordable automotive products in a highly competitive market by breaking a regionally and complexly integrated supplier chain that runs across North America. This in turn, may reduce the ability from the automotive industry to meet with global requirements in terms of quality and costs. Japanese investment flows to Mexico might be affected, but established firms in Mexico are expected to react by looking inwards and diversifying to the European and South American markets to lessen the effects from a more closed U. S. market. 
As a final note, with the devastating economic downturn caused by the Covid-19 pandemic and the new regulations under the USMCA, the automotive industry must adapt to a new way of doing business. More than ever there needs to be a close relationship between firms in the production chain, government, academic institutions, and other stakeholders to face the new challenges ahead; not doing so will bring the growing dynamism of the industry to a halt and set back the achievements reached. The new working conditions must bring about a new phase of supplier development that comply with the current and upcoming local content requirements and the industry must transition to new technologies and higher value-added activities related to design engineering and tool manufacturing.

\section{References}

Aoki, M. (1990). Toward an economic model of the Japanese firm. Journal of Economic Literature, 28(1), 1-27.

AP JETRO. (September 13, 2017). メキシコの現地自動車部品サプライヤ 一情報[Local Auto Parts Supplier Information in Mexico]. https://www. jetro.go.jp/world/cs_america/mx/autoparts.html

Arbia, G., Espa, G., \& Giulani, D. (2016). Analysis of Spatial Concentration and Dispersion. In C. Karlsson, M. Andersson, \& T. Norman (Eds.), Handbook of Research Methods and Applications in Economic Geography (pp. 135-157). Edward Elgar Publishing.

Asanuma, B. (1989). Manufacturer-supplier Relationships in Japan and the Concept of Relation Specific Skill. Journal of the Japanese and International Economies, 3(1), 1-30. https://doi.org/10.1016/0889-1583(89)90029-4

Belderbos, R., \& Carree, M. (2002). The Location of Japanese Investment in China: Agglomeration Effects, Keiretsu and Firm Heterogeneity. Journal of the Japanese and International Economies, 16(2), 194-211. https://doi. org/10.1006/jjie.2001.0491

Cámara Japonesa de Comercio e Industria de México. (9 September 2016). Directorio de la Cámara Japonesa de Comercio e Industria de México A.C. www.japon.org.mx

Cheng, S., \& Stough, R. (2006). Location decisions of Japanese new manufacturing plants in China: a discrete-choice analysis, The Annals of Regional Science, 40(2), 369-387. https://doi.org/10.1007/s00168-005-0052-4 
Clark, P.J., \& Evans, C.E. (1954). Distance to Nearest Neighbor as a Measure of Spatial Relationships in Populations, Ecology, 35(4), 445-453. https:// doi.org/10.2307/1931034

Dziczek, K., Swiecki, B., Chen, Y., Brugeman, V., Schultz, M., \& Andrea, D. (2017). NAFTA briefing: Trade benefits to the automotive industry and potential consequences of withdrawal from the agreement. Center for Automotive Research.

Ernst \& Young Global Limited. (September 13, 2017). New Government: Implications for the Mexican Automotive Industry. EY Report. https:// www.ey.com/en_gl/automotive-transportation

Falck, M. (2012). Japanese Foreign Direct Investment in Mexico and the Impact of the Global Crisis. Globalization, Competitiveness \& Governability, 6(1), 36-54. https://doi.org/10.3232/GCG.2012.V6.N1.03

Falck, M. \& Guzman, L. (2018). Japanese Direct Investment in Mexico's Transport Equipment Sector. Macro Impact and Local Responses. Springer Nature

Global Business Reports. (2016). Mexico's Regional Automotive Report 2016. Global Business Reports.

Granados, U. (2016). Mexico and Japan, Coping with the Multilateral Trade Crisis. Negocios Promexico, 16-19.

Guzman-Anaya, L. (2015). Localization Factors from Japanese Firms in Automotive-related Industries in Mexico. Procedia Economics and Finance, 30, 265-270. https://doi.org/10.1016/S2212-5671(15)01294-0

Guzmán-Anaya, L. (2017). Spatial Determinants of Japanese FDI Location in Mexico. México y la Cuenca del Pacífico, 6(17), 13-35. https://doi. org/10.32870/mycp.v6i17.526

Guzman-Anaya, L. (2018). Locational Determinants of Japanese Automotive FDI in Mexico: A Spatial Analysis. In M. Falck \& L. Guzmán-Anaya (Coord.), Japanese Direct Investment in Mexico's Transport Equipment Sector. Macro Impact and Local Responses. Springer. https://doi.org/10.1007/978981-10-7718-0

Hayashi, T. (2012). Agglomeration economies and location choice: a study on Japanese automotive suppliers in China. Shougaku ronshu, 81(1), 23-43.

Head, K., Ries, J., \& Swenson, D. (1995). Agglomeration benefits and location choice: evidence from Japanese manufacturing investment in the United States. Journal of International Economics, 38(3/4), 223-247. https://doi. org/10.1016/0022-1996(94)01351-R 
Japan Bank for International Cooperation. (February 15, 2016). Survey Report on Overseas Business Operations by Japanese Manufacturing Companies. http://www.jbic.go.jp/en

Japan External Trade Organization. (August 14, 2019). Japan's Outward and Inward Foreign Direct Investment. https://www.jetro.go.jp/en/reports/ statistics/

Jordaan, J. A. (2012). Agglomeration and the Location Choice of Foreign Direct Investment: New Evidence From Manufacturing FDI in Mexico. Estudios Económicos, 27(53), 61-97. https://doi.org/10.24201/ee.v27i1.95

Kakihara, T., \& Guzmán-Anaya, L. (2014). Factores de Localización de la Inversión Extranjera Directa Japonesa en México. In T. Okabe \& S. Carrillo (Coord.), Relaciones México-Japón en el contexto del Acuerdo de Asociación Económica. (pp. 135-173) Juan Pablos Editor.

Keizai, T. (November 19, 2016). Kaigai Shinshutsu Kigyo Soran [Japanese Overseas Investment]. http://dbs.toyokeizai.net/en/

Kondo, K. (2018). Sourcing patterns of export-platform foreign affiliates: The case of Japanese affiliates in Mexico. World Economy, 41(5), 1-20. https:// doi.org/10.1111/twec.12579

Krugman, P. (1991). Geography and Trade. The MIT Press.

Lichtensztejn, S. (2014). La Inversión Extranjera Directa en México (1980-2011) Aspectos Cuantitativos y Cualitativos in Inversión Extranjera en Países Emergentes en Transición. Universidad Veracruzana

Martin, X., Swaminathan, A., \& Mitchell, W. (1998). Organizational evolution in the inter-organizational environment: incentives and constraints on international expansion strategy. Administrative Science Quarterly, 43(3), 566-601. http://dx.doi.org/10.2307/2393676

Maurel, F., \& Sedillot, B. (1999). A Measure of Geographical Concentration of French Manufacturing Industries. Regional Science and Urban Economics, 29(5), 575-604.

Mexico Business Publishing. (January 22, 2020). Mexico Automotive Review 2019/2020. https://mexicobusinesspublishing.com/automotive/2020

Ministry of Economy, Trade, and Industry. (October 29, 2017). Quarterly Survey of Overseas Subsidiaries. http://www.meti.go.jp/english/statistics/ tyo/genntihou/index.html

Nakayama, S., \& Asayama, R. (January 25, 2020). Japan Auto Companies Triple Mexican Pay Rather than Move to US. Nikkei Asia. https://asia.nikkei. 
com/Business/Automobiles/Japan-auto-companies-triple-Mexican-payrather-than-move-to-US

International Organization of Motor Vehicle Manufacturers (OICA). (January 22, 2021). 2020 Statistics. https://www.oica.net/2020-statistics/

Reid, N. (1995). Just-in-time inventory control and the economic integration of Japanese-owned manufacturing plants with the county, state and national economies of the United States. Regional Studies, 29(4), 344-355.

Romero, Q. L., \& Andrés-Rosales, R. (2014). Técnicas Modernas de Análisis Regional. Plaza y Valdés.

Salas, B. (2016). Japanese Companies in Mexico Set to Top 1,000. Negocios Promexico.

Secretaría de economía. (August 28, 2017). Competitividad y Normatividad / Inversión Extranjera Directa: México. http://www.gob.mx/se/

Secretaría de economía. (January 20, 2020). Registro Nacional de Inversiones Extranjeras. Mexico. https://datos.gob.mx/busca/dataset/registronacional-de-inversiones-extranjeras-rnie

Smith, D. F., \& Florida, R. (1994). Agglomeration and Industrial Location: An Econometric Analysis of Japanese-Affiliated Manufacturing Establishments in Automotive-Related Industries. Journal of Urban Economics. 36(1), 23-41.

Torres-Landa, J. F., Romero, C., \& Corcuera-Bain, P. (January 22, 2019). Automotive in Mexico. Hogan Lovells. https://www.lexology.com/library/ detail.aspx?g=663197d1-99dc-4486-a873-bc76a451d0c2

United Nations Conference on Trade and Development (UNCTAD). (2020). World Investment Report 2020. International Production Beyond the Pandemic. United Nations. https://unctad.org/en/PublicationsLibrary/ wir2020_en.pdf

Wakasugi, R. (2005). The Effects of Chinese Regional Conditions on the Location Choice of Japanese Affiliates. The Japanese Economic Review, 56(4), 390-407. https://doi.org/10.1111/j.1468-5876.2005.00337.x

Yamawaki, H. (1991). Exports and Foreign Distributional Activities: Evidence on Japanese Firms in the United States. Review of Economics and Statistics, 73(2), 294-300.

Zhou, C., Delios, A., \& Yang, J. Y. (2002). Location Determinants of Japanese Foreign Direct Investment in China. Asia Pacific Journal of Management, 19, 63-86. https://doi.org/10.1023/A:1014839607180 